\title{
THE CHALLENGES ON SPATIAL CONTINUITY OF URBAN REGENERATION PROJECTS: THE CASE OF FENER BALAT HISTORICAL DISTRICT IN ISTANBUL
}

\author{
D. ERBEY \& A.E. ERBAS \\ Mimar Sinan Fine Arts University, Faculty of Architecture, \\ City and Regional Planning Department, Istanbul, Turkey.
}

\begin{abstract}
Urban regeneration projects in Turkey are the most important urban issues discussed and have social, economic and environmental aspects. In the last 10 years, many legislative regulations have been created by the national government in order to achieve urban regeneration. Today, urban space is produced by urban regeneration projects in Istanbul as it is in many other cities in Turkey. Urban regeneration practices are prepared not only for the former brownfield areas of the city but also for the historical urban environment. This raises heritage conservation issues for urban regeneration. The Fener and Balat district is one of the heritage sites located in the historical peninsula of Istanbul. This historical district has important features such as cultural enrichment, maintaining the urban identity and unique urban patterns. The EU-supported 'District Fener Balat Rehabilitation Program' was developed for the district after the 1996 Habitat II Conference in Istanbul. Urban regeneration projects have also been prepared for this historic district since 2006. In this paper, the urban regeneration projects for Fener Balat district will be analyzed, and the results will be discussed based on the technical expertise reports of administrative court proceedings and related to some results of the graduate theses supervised by the authors in the last 10 years. The spatial continuity of the Fener Balat regeneration project is discussed along with weak governance, disconnection with the socioeconomic context and the lack of modern conservation principles for the protection of historical urban patterns. The study argues that the project risks spatial fragmentation, degeneration, disidentification, alienation and gentrification.

Keywords: planning for historic areas, spatial continuity, urban regeneration projects.
\end{abstract}

\section{INTRODUCTION}

Urban regeneration, which has been a significant issue for urban planning in England and the U.S. since the 1980s, is the ensemble of holistic and integrative visions and operations for improving economic, physical, social and environmental conditions of a region in flux. Urban regeneration means transforming regions in physical and social recession into liveable and lively places by activating dynamics of local economy and enabling cities to rehabilitate them [1]. After 1980s, new urban policies were created with deindustrialization and neo-liberalism in cities. These policies were created to preserve social programs that generate new infrastructures, investment regions, education and employment and to conserve natural and historical urban fabric. A transformation in urban policies was experienced in this period by the common action of private capital and city governments in global cities. Smith defines this association as the association of private capital and local governments and notes that in the 1990s liberal urban policies become common in cities. The urban regeneration approach developed with these liberal urban policies brought public and private investors together [2]. However, in cities that are not governed by liberal urban policies, urban regeneration has 
evolved differently. Competitive urban strategies affected by global markets became active in the historical centres of these cities.

Since the proclamation of the Republic, Turkish cities have created physical spatial plans for physical issues, unlike the development of Western cities. Strategic spatial plans were not on the agenda of cities until recently. The preservation of historical urban areas was governed by Law no. 2863. Development plans_-physical plans for the sites specified by this lawwere created and implemented for preservation. However, since the 1980s, the role of city centres - areas of interest in Turkish cities-has changed and attracted investors. The national government and city governments were intended to improve buildings against acts of god such as earthquakes, to revive depressed areas, to activate urban economies, to provide highquality residences and to increase international competitiveness. They also searched for new means of implementation and development methods for preparing the infrastructure of these plans $[3,4]$.

A new law that supersedes Law no. 2863, which limits the building new structures in historical urban areas and physical modification of built-up areas, eased the resolution of difficult property issues and increased the operational power of governments. Regeneration Law no. 5366 was enacted with the purpose of implementing urban regeneration in urban sites.

Practices in historical urban areas differ from urban regeneration in slums because of many physical and social issues and unplanned development. They have the very significant mission of ensuring historical and cultural sustainability [5].

The recognition that change is an inherent part of urban development and conservation is thus integral to its management in historical areas that call for continuity and coherent substitution [6]. Historical and cultural sustainability are the main principles of conservation. In addition to the social, cultural and physical values of environments, their intangible values should also be conserved. Projects and plan decisions that fail to address holistically the physical and cultural values of environments risk of creating new conservation and sustainability problems [7].

\section{THE FENER AND BALAT HISTORIC DISTRICTS IN URBAN AGENDA}

The Fener and Balat District is located on Vodina Street parallel to the old sea walls of Istanbul. It consists of built-up areas along the Golden Horn's shores and open and green areas on the shore (Fig. 1).

Fener is located on the Fatih District on the west side of the Golden Horn. Balat is located northwest of Fener. The neighborhoods of Fatih are located to the west and southwest, and Ayakap 1 is to the south. The main street starting from the Golden Horn Bridge and leading to Eminönü is a significant traffic route. This traffic route divides the area into two parts. The first part is the open and green area situated between the road and the Golden Horn. This area was built after the demolition of industrial areas along the Golden Horn shore. Traces of the old industrial buildings on the ground can only be followed on old maps. The second part is a neighborhood located on the west side of the road and used for housing. These neighborhoods are: Abdi Subaşı, Tahta Minare and Tevkii Cafer with traditional urban fabrics. The area has a traditional trade centre. Houses, commercial buildings, religious facilities and education facilities, which are examples of monumental and civil architecture, are located around the centre [8]. The fact that this district was called 'Fanarion' in the Ottoman Era indicates that there was a significant lighthouse located on the shores of the Golden Horn. People used the Fener Door in the sea walls to enter Fener District. The door connected Mürsel Paşa Street and Abdülezel Paşa Street, where the Bulgarian St. Stephen's church is 
located. The significance of Fener is that it is the district where some well-known Byzantine families, who immigrated to various counties after Istanbul was conquered by the Ottoman Empire, resettled when they came back to Istanbul as a result of reorganization. This district has international significance as a center for the Orthodox church and for other churches in the area. The fact that the Patriarchate is located here also contributes to this significance. Fener and adjacent regions were places where generally Greeks and Jews resided. The residents of the district who worked in the trade sector and had duties in the Ottoman state, earned high incomes from their jobs, making it a socio-economically active district. The mansions of well-known families were located along the shore in Fener in the 18th and 19th centuries. The neighborhoods of the region-consisting of stone and wooden buildingswere reorganized after the fires. They have a vertical and orthogonal street structure and rise toward Fatih and Çarşamba.

It is possible to see that the section right next to the walls did not change until the first half of the 19th century and had a traditional structure, although this section is located in a part of Istanbul that experienced frequent fires. After the 1930s, there were changes in shore usage generated by industrial planning decisions, and the mansions were replaced with factories and storage facilities. However, the most important change was the destruction and reorganization of Fener's shores as open and green areas with the restoration of the Golden Horn launched by Istanbul Municipality in 1985. The Fener District was heavily populated by Greeks until the 1940s. Industrial factories affected the district, as did the fact that certain immigrants preferred to reside in this area due to its proximity to business centres and low rents. Wearing, aging and losses were thus seen as a result of its socio-economic structure. Changes in the employment situation with the destruction of industrial facilities in the middle of the 1980s played a key role in this.

Balat is located between Fener and Ayvansaray on the historic peninsula. Balat is a significant district, which hosted Macedonian Jews and immigrants from Spain at one time. A great deal of commercial activity took place there since Balat Pier was used for shipping in the 17th century. Piers such as Ayvansaray, Balat and Fener are known to be significant since they supported the traditional centre in Eminönü on the Golden Horn shore and ensured the movement of goods and people. The area on the inner side of the walls and parallel to the walls was the most active and the centre of Balat. Important synagogues of the Jewish community are located there. One of the significant factors that affected Balat was fire. Large
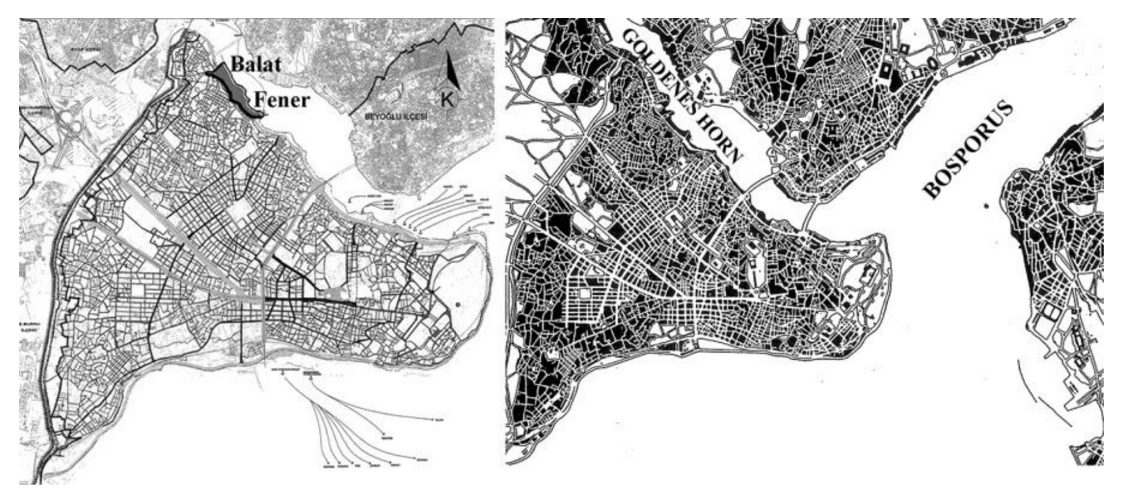

Figure 1: Fener Balat Regeneration Project Area in Historical Peninsula and historical urban pattern of the project area [3,9]. 
avenues and streets on the inner side of the wall are known to be in an organized settlement, and it is possible to see vertical street structures there [10,11].

The factories along the shores of Balat were built with the permissions for industrial activities. There were changes in its socio-economic structure, but the significant ones were in its social, environmental and economic structure with the destruction of these factories in the middle of the 1980s. The Golden Horn shores in Istanbul, located at the heart of intense immigration to Turkey, received their share due to the industrial facilities built along them in the first half of the 20th century. In addition, the transformation caused by population exchange was sped up by changes in industrial employment. After the second half of the 1980s, all the industrial facilities along the shore that were reported to be polluting were demolished to restore the Golden Horn shores, which were reorganized as an open and green area. In addition to the changes in physical structure, the population also changed, and significant changes were also experienced in employment as a result of this development. Wearing and aging affected the physical structure due to the fluid socio-economic structure. After the early wave of immigration, several generations resided in these regions. Spatial and social structure in Fener and Balat differ from those of districts such as Tarlaba 1 and Sulukule that may be thought to resemble them. The differences are the District Fener Balat Rehabilitation Program supported by international organizations such as the EU and UNESCO and the closeness of families who have lived in a neighborhood culture for several generations $[9,12]$.

\section{FENER AND BALAT IN THE METROPOLITAN PLANNING PROCESS}

Fener and Balat are on the Golden Horn, the issues of which have been addressed by a variety of planning decisions and practical means since 1985. The main specification of these plans is to open the shoreline to the people, demolish polluting industrial facilities in both the city centre and along the Golden Horn and enable urban functions to relocate. These main policies in larger scale plans appear to be implemented higher provisions in smaller scale plans. The first large-scale plan for the Istanbul Metropolitan Region was approved by the Ministry of Development and Housing on July 29, 1980. This plan is the highest level plan for decisions concerning the Golden Horn. This plan aims to address and evaluate various thorny environmental issues for the Golden Horn and adjacent regions. Water contamination which emerged due to the long-term lack of inspection and the Golden Horn basin's borders were noted in the plan, indicating that these issues will be addressed as a whole to solve poor housing and urban functions. Main principles were to analyze each type of urban function polluting the Golden Horn basin in the large-scale plan, to eliminate manufacturing and industrial pollution from the Golden Horn, to connect the main transportation system and improve urban logistics by relocating elements used by the city such as the marketplace and dry foods, to expropriate houses in poor condition on the Golden Horn and make their locations open areas, to close industrial facilities and quarries on the Alibeyköy and Ka thane streams in the Golden Horn basin, to remove every activities that bear the risk of polluting the Golden Horn from the Golden Horn shores and to build public spaces in the former locations of polluters.

After Istanbul Metropolitan Area studies were approved by the Ministry of Development and Housing on July 31, 1980, addressing solutions and new measures for the Istanbul metropolitan area became the main issues for studies under the 1/50,000 scaled plan principles and the approval granted to local governments by Development Plan Law No. 3194. Arrangements for the Golden Horn were included in studies for opening the shores in the Istanbul metropolitan area and removing harmful and polluting manufacturing facilities from 
the city. After Law No. 3194 came into force, the mayorship of the Metropolitan Municipality of Istanbul approved the 1/5000 scaled Golden Horn Arrangement Master Development Plan, approved on December 19, 1985, in accordance with the principles and purposes implied by the large-scale plan. Arrangements for the Golden Horn were performed as per the lowerscaled plans with the cultural and recreative planning purposes of removing the manufacturing industry along the Golden Horn with the Golden Horn Arrangement Master Development Plan, moving the marketplace, dry food, small and large industrial facilities out of the central work area and placing them in areas appropriate for their functions, reorganizing the Golden Horn shores as open to public. Operations for the coordination of practices with other institutions were also implemented after 1985 [9].

Addressing and evaluating the Golden Horn shores as a whole in a plan after the 1980s and using this area as a place open to every section of society, cultural areas and recreational areas and other functions were clearly mentioned by planning policies. Additionally, provisions related to the registration of immovable cultural heritage sites were included in this plan. However, identifying and registering the cultural heritage sites in an area ruled by many different cultures at different times is a slow and laborious process [2]. Information, findings and documents indicate that there are still unregistered and unknown cultural heritage sites in the area. In addition to all plans and development operations, the fact that the Habitat II Conference was held in Istanbul in 1996 enabled a new project for Fener and Balat districts. The principle of 'adopting urban policies that respect social and environmental rights' included in the final declaration of Habitat Conference meant that District Fener Balat Rehabilitation Program was developed using a participatory approach. We are aware of the fact that creating a project, capturing interest at the international level, including multiple forms of participation are parts of restoration works conducted with the support of technical teams according to agreements made with the European Union. This means establishing social centres, turning the historic Balat Bazaar into an attraction centre and cooperating with the people of the district in waste management. Donations have been made for the restoration of houses, and restoration work has been partially completed according to contracts with the property owners and the building and restoration information form. The 1/5000 and 1/1000 scaled 2005 Conservation Plans to Protect the Historic Peninsula were approved by the Protection Committee after certain studies were conducted [9].

However, the 1/5000 scaled Conservation Plan to Protect the Historic Peninsula (Eminönü and Fatih) was nullified by the Istanbul Eighth Administrative Court's resolution no. K: 2007/2444 dated 11/29/2007. The 1/1000 scaled Fatih Conservation Plan for Protect, approved with Istanbul First P. and P.N.A. Regional Council's Resolution No. 402 dated 01/26/2005 was nullified by the Istanbul Fifth Administrative Court's resolution no. K: 2008/1950 dated 11/04/2008. Conservation Plans to Protect the Historic Peninsula came into effect with resolution no. 2327 dated 10/15/2010 for other project areas, including regeneration areas in the Fatih District, usage decisions related to industry, housing and trading, transportation links and significant reinforcement areas. The Analysis Sheets of the Conservation Plan for Protection include studies for the 1/5000 scaled Conservation Plan to Protect the Historic Peninsula related to areas covering the borders of Regeneration areas. It was approved by the Istanbul Regeneration Areas Regional Council for Protecting Cultural Heritage with resolution no. 101 dated 11/03/2011.

On the other hand, as a new conservation planning tool; Site Management Plan for Historical Sites of Istanbul was approved by UNESCO in 2011, revised in 2016. The management plan was prepared by both central and local governments, universities, 
nongovernmental organisations and local inhabitants coming together and constituting a vision, mission and main objectives and particularly within the frame of UNESCO Operational Guidelines for the Implementation of the World Heritage Convention and international agreements, regulations and principles of UNESCO and ICOMOS and its subsidiary organisation for the cultural heritage issues. The plan consists of general strategies which were determined by considering the contribution of the stakeholders as a consequence of a meticulous study under the headings of Management, Conservation, Planning, Quality of Life, Perception, Training, Awareness Raising, Risk Management and a range of action plans prepared in accordance with these strategies [12]

As it can be understood from these definitions, it will be possible to develop regeneration projects in accordance with the physical structure of urban environments and the socio-economic characteristics of people in poor residential areas specified by the authorities and also should be related to the UNESCO Guideline in international level. As indicated by the upperscale plans, regeneration projects will be developed in accordance with the studies for both physical structure and socio-economic characteristics of residents.

\section{CHALLENGES FOR THE FENER BALAT REGENERATION PROJECTS}

Fener and Balat host cultural sections from a variety of historical periods. A Transformation and Regeneration Project, started in 2006, was planned suggesting that settlement in this area was old and outdated. Significant resolutions amending city blocks in the area and spatial characteristics of the parcels are adopted in the regeneration projects (Fig. 2). This paper reviews and evaluates these regeneration and transformation projects.

The projects for Fener and Balat were reviewed within the current legal framework:

- Law no. 5366 dated 06/16/2005 and related to "Protection and Usage of Old Historic and Cultural Immovable Heritage Sites by Regeneration and Conservation"

- Law Governing Regulations no. 2005/9668 dated 12/14/2005 and related to "Protection and Usage of Old Historic and Cultural Immovable Heritage Sites by Regeneration and Conservation"

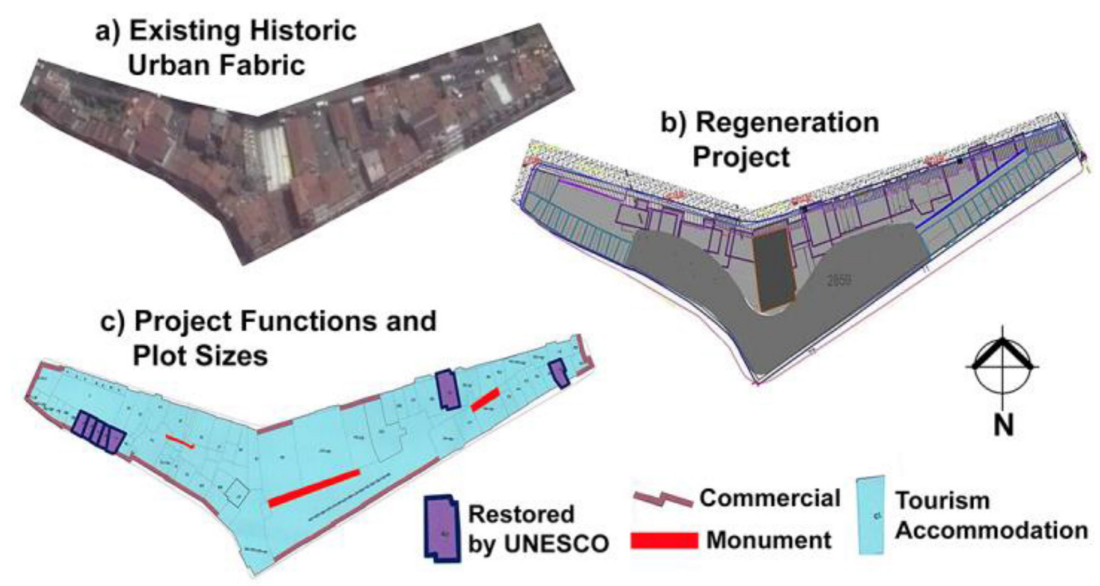

Figure 2: Spatial transformation in one of zoning island by Fener Balat Regeneration Project and degeneration of historical pattern. 
- Law no. 5835 dated 02/04/2009 and related to Amending the Law Protecting Cultural and Natural Assets

- Law no. 2863 dated 07/21/1983 and related to Protecting Cultural and Natural Assets

As per the Law no. 5366 on Protection and Usage of Old Historic and Cultural Immovable Heritage Sites by Regeneration and Conservation, Council of Ministers' resolution no. 2006/10961 published in the Official Gazette no. 26318 dated 10/13/2006 and is related to "Regarding Certain Areas in Fatih District of Istanbul as Regeneration Areas." Fatih Fener, Balat and Ayvansaray are within these borders. The following statement is included in the Council of Ministers' resolution no. 2006/10961: "As per the second article of the Law no. 5366 related to Protection and Usage of Old Historic and Cultural Immovable Heritage Sites by Regeneration and Conservation; regarding the areas, which are within the borders of Fatih District of Istanbul and block and parcel number of which are shown in the attached list, as regeneration areas was adopted by the Council of Ministers at 09/13/2006 upon the Ministry of Interior's letter no. 58807 dated 09/06/2006."

When these projects are reviewed, findings obtained within the context of Planning for Historic Areas and Spatial Continuity can be summarized as follows:

- Twenty-one parcels of 28, which are restored under the District FenerBalat Rehabilitation Project (FBRP), are included in the preliminary project although buildings that are restored under the District FenerBalat Rehabilitation Project (FBRP) conducted conjointly by EU and Fatih Municipality are defined as out of the project in the preliminary project.

- Amalgamation resolutions are adopted without considering sufficient analysis in terms of parcel and block, and new projects are created by amalgamating registered parcels.

- Plan solutions suggested in the Regeneration Preliminary Project indicate that genuine plan structures that should be protected for registered buildings were neglected, additions and classifications were suggested without considering the original apartments, basement floors were neglected and the parking area suggestions for these floors did not consider the basement floors of registered areas.

- One-hundred and three new parcels were generated as a result of the amalgamation implemented on 317 parcels on 17 blocks. The parcel structure that constitutes the genuine characteristic of the environment was terminated, and the current genuine structure was spoiled with the newly generated parcels (Fig. 3).
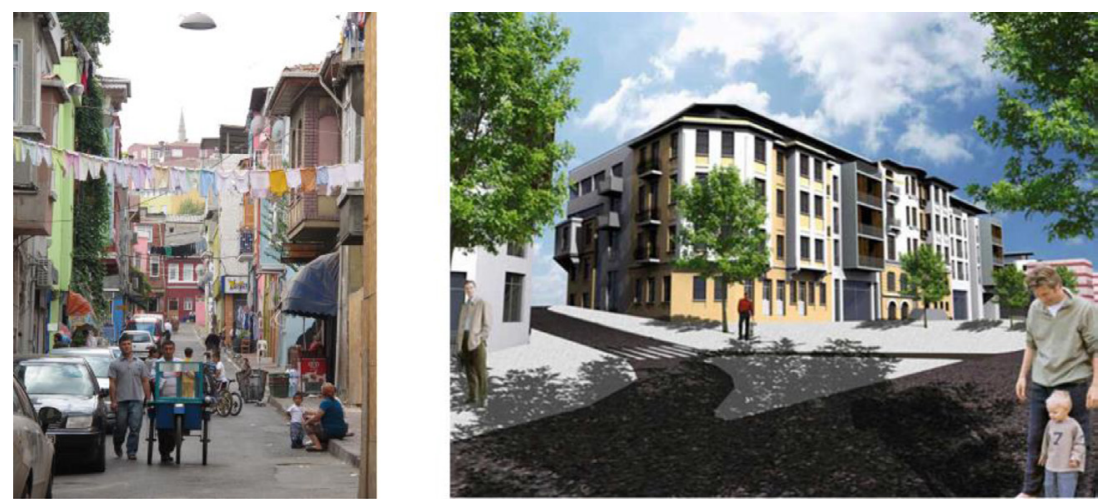

Figure 3: Existing neighborhood structure and proposed spatial project in historical district. 
- Walls between the buildings in blocks are demolished as provided by the preliminary projects, new floors are added and specifications of historical heritage are demolished due to the fact that town houses or line characteristics with new front organizations are built.

- It was detected that half of the buildings in building blocks are registered buildings. Additionally, surveys which bear the architectural specifications of registered buildings that should be protected and would direct the restoration projects were not included in the preliminary project. Only 13 of 567 parcels, 290 of which are registered, on 19 building blocks have basement floor surveys, 122 have ground floor surveys and 121 have first floor surveys.

- Presence and surveys of basement floors of registered buildings were highlighted in only 13 of 290 registered buildings in the preliminary project. Parking area suggestions for these floors were not made considering the basement floors of the registered buildings.

- While specifying the functions suggested for the building blocks, decisions were not made considering the architectural specifications of the registered buildings that bear the characteristics of building blocks and should be protected.

- Preliminary projects indicate that the street orientation of building blocks was not shown in sections, and street integrity was not observed.

\section{CONCLUSIONS}

Other than the international agreements for protecting architectural heritage, the protection principles and bylaws of the organizations such as UNESCO and ICOMOS are significant directives. Ensuring historical and cultural sustainability is significant for planning and designing historic environments. However, it is clear the regeneration projects for Fener and Balat do not observe international protection principles and bylaws. When ensuring historical and cultural sustainability is evaluated, the points that should be considered in a regeneration project can be summarized as follows:

- As specified by UNESCO's "The Protection and Contemporary Role of Historic Areas" (Warsaw-Nairobi 1976) and many international documents, the phrase "protecting historic cities and urban areas" covers the process of conserving historic cities and urban areas legally, steps for their restoration and adaptation to development and participation in contemporary life.

- In addition to their historical specificity, these areas also bear the values of traditional urban culture. Today, historical cities and urban areas are exposed to threats with the urban changes that accompany industrialization. They are neglected, ruined and even demolished.

- ICOMOS (the International Council on Monuments and Sites)—an international nongovernmental organization for protecting cultural heritage sites against this irremediable situation causing cultural, social and even economic losses, and an adviser institution to UNESCO_defined principles, purposes and methods related to protecting historic cities and areas in the international bylaw called THE CONSERVATION OF HISTORIC TOWNS AND URBAN AREAS, which was prepared to complete the Venice Charter. This bylaw aims to protect private and public residential areas in historical cities and regions and support the conservation of the cultural values, even if they are minor, which constitute the memory of humanity.

- The success of the conservation program, as specified as the principles and methods in the bylaw, The Conservation of Historic Towns and Urban Areas, is possible with the 
participation of the people living in urban areas. Therefore, the participation of the people should be encouraged. Conserving historical towns and urban areas interests primarily their residents. The specifications that should be conserved are the historical characteristics of the city and their physical and immaterial components. Urban structure defined by parcels and streets, relations between the buildings and green and open areas, scale, size, style and building style, components, the color and ornaments of buildings and the inner and outer appearance of buildings are among the different specificities attributed to historical cities and urban areas. Negative factors that threaten them may spoil the authenticity of the historical cities and urban areas.

- Authenticity value - the most important value to be conserved-consists of style and design, components and patterns, usage and function, traditions and methods, place and location and spirit and emotion. This value constitutes the identity of culture, so it is indispensable and inevitable for conservation [13]. In accordance with the conservation approach related to understanding buildings and urban structure, recognizing their history and meaning, ensuring their material conservation, restoration and assessment, contemporary conservation concepts and principles should be adapted to contemporary life. It is impossible to describe the "Design-Component-Labor-Environment" of these buildings, which turn into empty shells. Addressing all of these buildings as shells and regenerating them, for example, as theater decors for the purpose of maintaining the visual sustainability of urban structure cannot be included in urban and single building conservation.

- New functions and activities should be compatible with historic urban areas for the conservation of historic sites. The processes of providing necessary technical services and improving them should be conducted with caution to adapt them to contemporary life. Improving houses should be one of the main aims of conservation. When new buildings need to be built or old ones adopted, current spatial entities should be observed. In particular, the scale and parcel size should be observed.

Urban regeneration approach nothing but improvement of physical environment without considering the spatial continuity creates completely new urban areas which has never been in exist in historical neighborhoods. The new spaces created by the projects also create new life styles by destroying the traditional and local social networks and meanings. Besides the economic and physical benefits, neighborhood regeneration has a crucial mission of spatial and social, cultural continuity.

\section{REFERENCES}

[1] Roberts, P., The evolution, definition and purpose of urban regeneration. In Urban Regeneration: A Handbook, eds. P. Roberts \& H. Sykes, Sage Publications, p. 17, 2000.

[2] Smith, N., New globalism, new urbanism: gentrification as global urban strategy. Antipode A Radical Journal of Geography, 34(3), pp. 427-450, 2002.

[3] Erbas, A.E. \& Erbil, T. Neoliberal challenges and practices of urban regeneration projects in Istanbul. Real Corp Conference, "Planning Times, You Better Keep Planning or You Get In Deep Water, For The Cities They are a-changin” pp. 843-852, 2013.

[4] Erbas, A.E., Ecological approach to planning studying samples of Istanbul within the framework of sustainable urban development, MSc Thesis, Mimar Sinan Fine Arts University: Istanbul, 1995.

[5] Erden, D., Urban projects as a tool for urban regeneration, PhD Thesis, Mimar Sinan Fine Arts University: Istanbul, pp. 10-12, 2003. 
[6] Jokilehto, J., The Historic Urban Landscape Recommendation; from the Proposal to the Implementation, Historic Urban Landscape Meeting, MimarSinan Fine Arts University: Istanbul, 2014.

[7] Assmann, J., Kültürel Bellek, Trans. A. Tekin, Ayrıntı Publications: Istanbul, p 21. 2001.

[8] Akın, N., Balat, Dünden Bugüne Istanbul Ansiklopedisi. Ministry of Culture and History Foundation Publication: Istanbul, 2, pp. 10-12, 1993.

[9] Conservation Plan Reports of Historical Peninsula, Istanbul Metropolitan Municipality, City Planning Directory, 2003, 2005, 2011.

[10] Erden, D., Affects of socio-economic dynamics on urban conservation, MSc Thesis, 0: Istanbul, pp. 22-24, 1994.

Istanbul Historic Peninsula Site Management Plan Report, Istanbul Site

[11] Akın, N., Fener, Dünden Bugüne Istanbul Ansiklopedisi, Ministry of Culture and History Foundation Publication: Istanbul, 3, pp. 279-281, 1993.

[12] Istanbul Historic Peninsula Site Management Plan Report, Istanbul Site Management Directory, p. 5, 2011.

[13] Morley, D. \& Robins, K., Space of Identity, Routledge, p.107, 2002. 